$\stackrel{N / 2}{N}$

Global Journals Inc

s.

GLOBAL JOURNAL OF MANAGEMENT AND BUSINESS RESEARCH: A

ADMINISTRATION AND MANAGEMENT

Volume 19 Issue 10 Version 1.0 Year 2019

Type: Double Blind Peer Reviewed International Research Journal

\title{
Impact of Microcredit Programs on Women Empowerment in Bangladesh: A Comparative Study of Grameen Bank and BRAC
}

\author{
By Noman Hasan, Sayma Hossain Shetu, Brishti Chakraborty \\ \& Abdul Gaffar Khan \\ Mawlana Bhashani Science and Technology University
}

Abstract- The purpose of this paper is to investigate the effects of microcredit programs on women empowerment in Bangladesh, especially in rural areas, by making a comparative study of Grameen Bank and BRAC. In this study, both primary and secondary data were used. Primary data were collected by a household questionnaire survey in Tangail district. Percentage analysis, cross-tabulation, and paired t-test had been used to analyze and interpret the data. Secondary data were retrieved from different books and magazines, internet and related journals, and project papers. The results showed that microcredit programs of Grameen Bank and BRAC have a significant impact on women empowerment in Tangail district, Bangladesh. The research was limited to Tangail region, and only two NGOs were taken into consideration while collecting primary data. The policymakers can utilize these research findings while making policies on women empowerment. This study will also encourage different other NGOs to broaden their microcredit programs as well as the women to take microcredit and change their fortune.

Keywords: microcredit, women empowerment, NGOS, economic development.

GJMBR-A Classification: JEL Code: M10

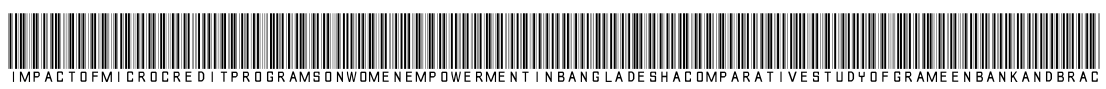

Strictly as per the compliance and regulations of:

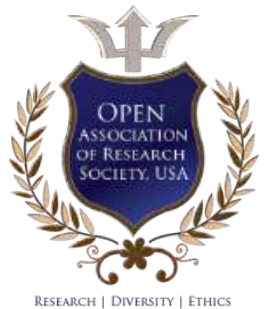

(C) 2019. Noman Hasan, Sayma Hossain Shetu, Brishti Chakraborty \& Abdul Gaffar Khan. This is a research/review paper, distributed under the terms of the Creative Commons Attribution-Noncommercial 3.0 Unported License http://creativecommons. org/licenses/by-nc/3.0/), permitting all non-commercial use, distribution, and reproduction in any medium, provided the original work is properly cited. 


\title{
Impact of Microcredit Programs on Women Empowerment in Bangladesh: A Comparative Study of Grameen Bank and BRAC
}

\author{
Noman Hasan ${ }^{\alpha}$, Sayma Hossain Shetu ${ }^{\circ}$, Brishti Chakraborty ${ }^{\circ} \&$ Abdul Gaffar Khan ${ }^{\omega}$
}

\begin{abstract}
The purpose of this paper is to investigate the effects of microcredit programs on women empowerment in Bangladesh, especially in rural areas, by making a comparative study of Grameen Bank and BRAC. In this study, both primary and secondary data were used. Primary data were collected by a household questionnaire survey in Tangail district. Percentage analysis, cross-tabulation, and paired ttest had been used to analyze and interpret the data. Secondary data were retrieved from different books and magazines, internet and related journals, and project papers. The results showed that microcredit programs of Grameen Bank and BRAC have a significant impact on women empowerment in Tangail district, Bangladesh. The research was limited to Tangail region, and only two NGOs were taken into consideration while collecting primary data. The policymakers can utilize these research findings while making policies on women empowerment. This study will also encourage different other NGOs to broaden their microcredit programs as well as the women to take microcredit and change their fortune.
\end{abstract}

Keywords: microcredit, women empowerment, NGOS, economic development.

\section{INTRODUCTION}

W omen are about half of the total population in Bangladesh and true economic development of Bangladesh, ignoring half of its population is quite impossible. Historically, women in Bangladesh are socially and economically deprived than men. Disparities between men and women exist here in education, health, employment and income generation opportunities, control over assets, personal security and participation in the political process that make women disadvantaged and less empowered, which limits the country's ability to achieve its full potential (MOWCA, 2008). Sarumathi and Mohan(2011) argued that gender discriminating societies experience higher poverty rate, slower economic prosperity, weaker governance, and lower living standard of people. So women empowerment is very much essential as it is strongly related to economic development (Duflo, 2012). Shahnaj Parveen and Ingrid-Ute Leonhauser (2004) showed that

Author a $\sigma \rho$ : Lecturer, Department of Business Administration, Mawlana Bhashani Science and Technology University, Bangladesh. e-mails: Sayma05mbstu@gmail.com, nomanhasan.du@gmail.com, brishtichakraborty.bba.mbstu@gmail.com

Author w: Assistant Professor, Department of Business Administration, Mawlana Bhashani Science and Technology University, Bangladesh. e-mail: gaffar.mbaiu@gmail.com

Corresponding Author: Sayma05mbstu@gmail.com the distribution of empowerment indicators show that $83 \%$ of the women have a very low economic contribution, $44 \%$ have a very low access to resources, 93\% have a very poor asset ownership, $73 \%$ have a moderate participation in household decision-making, $43 \%$ have a highly unfavorable perception on gender awareness and $72 \%$ have a moderate to high coping capacity to household shocks. Moreover, women have limited access to investments in skills, knowledge, and lifelong learning compared to the men. Therefore, their active engagement in economic activities is essential for economic growth and nation-building (Duflo, 2012). Women empowerment in Bangladesh through the formal credit programs of the different authorities (banks) is a bit difficult as most of the poor women remained outside of the reach of that credit programs (Hossain, Islam, \& Majumder, 2016). Micro-credit programs had been evolved as an effective tool to engage the women in the credit process. Most of the micro-credit programs intentionally target women as they have limited access to credit, have limited access to employment opportunity, have less authority in household decision making and have higher records of loan repayment compared to the men (Rahman, Khanam, \& Nghiem, 2017). Thus, women are with low credit risk and are more likely to share the benefits of the credit with their family members, especially their children (Rahman et al., 2017). Micro-credit programs are an effective system, as unlike formal Ioan provider institutions (banks), these targeted programs make the individual scattered poor women into groups, provide them training facilities, ask them to save a small amount of money, and help them to find a source of employment for generating income (Pitt \& Khandker, 1996). That is why women engagement in the labor force was increased to 35.6 percent in 2016 compared to 4 percent in 1974 (The Daily Star, 2018). By considering all these, the main objective of this study is to investigate the effects of microcredit programs on women empowerment in Bangladesh especially in rural areas by making a comparative study of Grameen Bank and BRAC, the two top NGOs in Bangladesh which also have international exposure. The Grameen Bank was formed in 1976 when professor Muhammed Yunus launched a research project to examine the possibility of designing a credit system targeted to the rural poor. In 
October 1983, the project was transformed into an independent bank named the Grameen Bank. In 2006, the Grameen Bank and Muhammed Yunus were jointly awarded the Nobel Peace Prize.The organization is built around a group-based credit approach that utilizes peer. pressure within the group to ensure that the borrowers follow through with their payments. As stated earlier, the government of Bangladesh has fixed the flat interest rate that microfinance institutions can charge at 11 percent. The Grameen Bank has a total of 8.39 million active borrowers of whom 97 percent are women. It operates via 2,567 branches in 81,386 villages in Bangladesh (Graflund, 2013). BRAC is as of November 2012 the largest non-governmental organization in the world, measured in the number of people it has helped. It was established in 1972 and is no present in all districts of Bangladesh and Pakistan, Sri Lanka, Uganda, Tanzania, South Sudan, Sierra Leone, Liberia, Haiti, and the Philippines. BRAC currently serves 4.39 million Bangladeshi individuals, most of who are women. BRAC has two forms of microcredit: one called Progoti, which is given for both men and women, and one called Dabi, which is given exclusively for women. The Dabi microcredit program ranges from USD 50 to 700 , given in Taka, and is given in a group setting that is labeled the Village Organization (VO). The VO, each with $30-40$ women, function as a platform for poor women to come together, exchange information, and raise awareness on social issues concerning their daily lives. Furthermore, the VO works as an informal guarantor by creating peer pressure in the group for regular repayments. Borrowers repay their loans via weekly installments at a flat interest rate of 11 percent during $\mathrm{VO}$ meetings held in the borrower's village. These loans are generally used for small operations poultry, livestock, or handicraft (Graflund, 2013).

The rest of the paper is organized as follows-the following section reviews related literature towards the development of hypotheses. The conceptual framework is discussed in section three. Section four and five are followed by methodology, and result and discussion of the study. In section six, conclusion and recommendations are set. Finally, the paper is ended with the limitations of this paper and future research directions in section seven.

\section{il. Literature ReVIEW}

Khandker and Pitt (1998) showed the impact of microcredit on income using a double-difference approach between eligible and ineligible households and between microcredit program villages and nonprogram villages by focusing three major microfinance institutions: Grameen Bank, Bangladesh Rural Advancement Committee (BRAC), and Bangladesh Rural Development Board (BRDB). The main finding was that microcredit programs had a positive effect on household consumption, especially for female borrowers. Kabeer (2001) examined the relationship between microcredit and women empowerment by interviewing both female and male microcredit program participants in two provinces in Bangladesh. The conclusion from her study was that women who received microcredit had higher self-worth and better access to capital. Even if participating in a microcredit program in some cases led to a higher workload, the women think positively about their increased contribution to the household income.

Furthermore, she found that in many cases, microcredit increased women's decision-making ability within the household. Goetz and Sen Gupta (1996) surveyed to show the effect of microcredit on women empowerment. A five-point index of loan control was used with the following measurements: full, significant, partial, very limited, and no involvement as an indicator on women empowerment. They found that in $37 \%$ of the cases, women retained full or significant control over the loan, and $22 \%$ of the cases women had no involvement in the loan process. They also showed that married women compared to unmarried women, had exercised less control over their loans. Hashemi, Schuler, and Riley (1996) found that the Grameen Bank and BRAC had significant positive effects on women empowerment. They chose six villages where the Grameen Bank and BRAC both operate and collected data through participant observation and informal interviews. They used a combination of sample survey data and case study approach to argue that the success of the Grameen Bank in empowering women is due to its strong central focus on credit, and its skillful use of rules and rituals to make the loan program function. Mizan (1993) used an index called the Household Decision Making (HHDM) scale, which was composed of questions on matters such as decision of food purchase, education and marriage of children, expenses on medical for self and husband, the woman's business earnings, purchase and sale of land, hiring of outside labor, purchase of agricultural inputs, the provision of financial support to husband's family and purchase of clothes for self and other household members. He showed that the member of years of borrowing from the Grameen Bank has a positive and significant effect on the HHDM score. Sarumathi and Mohan (2011)used psychological, social, economic indicators to examine the role of microfinance in empowerment in Pondicherry region and revealed that microfinance assisted women in gaining psychological and social empowerment than economic empowerment. King (2008) concluded that microfinance helped to bring poor people out of poverty, although, all microfinance programs are not equally proficient. Malathi and Vijayarani (2012) examined the relationship between microfinance and women empowerment in rural areas of Cuddalore district of Tamil Nadu in India. Chi-square 
and t-test were performed to analyze the data using 100 sample sizes. Findings of this study revealed that microfinance helped women in gaining empowerment. Empowerment was judged on the basis of economic position before and after joining the SHG program and education respectively. Le and Raven (2015) revealed that microfinance helped many women in their businesses, but had a limited effect on empowering women, creating upward mobility and contributing to long-term economic growth. Sanyal (2009) found that microfinance had a positive influence on women's social capital and normative influence, facilitating women's collective empowerment. Hussain and Nargis (2008) found that the longer a woman participated in microcredit programs, the more employment opportunities she had. Further, there was more scope that she might decide to buy productive and nonproductive assets. Naved (1994) showed that women were more active in household decision making and had more control over household income after participating in microcredit programs. Moreover, participation in microcredit programs helped to increase women's welfare and reduce male bias. Aruna and Jyothirmayi (2011) examined the influence of microfinance on women empowerment through regression analysis in Hyderabad, India. Results revealed that microfinance had a significant influence on socio-economic indicators. These indicators were considered as economic position, decision making power, knowledge, and self-worthiness. Sultana and Hasan (2010) conducted a study to know the impact of micro-credit on economic empowerment of rural women at Gazipur district in Bangladesh using stratified random sampling technique. The half sample study of (45 women) had involvement with microcredit program and rest half had no involvement with any other form of micro-credit program. These both groups belonged to the same socio-demographic profile. Results revealed that women involved with micro-credit program were more benefited than the control group. Moyle, Dollard, and Biswas (2006) found that women in income-generating activities gave support to personal and economic empowerment. Pitt, Khandker, and Cartwrighy (2003) found that participation in microcredit programs helped women to have access to financial and economic resources, a significant role in household decision making, greater social networks, greater communication in general and knowledge about family planning and parenting concerns and greater freedom of mobility. Longwe and Clarke (1994) explained women empowerment as an on-going cyclical process having five stages. The first stage was the welfare stage, the second was the access stage, the third stage was the conscientization level stage, the fourth stage was the participation level stage, and the final stage was control stage. This control increased women's power and respect within their households, communities, and societies at large. According to Pillai (1995), women empowerment is an active, multidimensional process which enables women to realize their full identity and powers in all spheres of life. Power is neither a commodity to be transacted, nor can it be given away as alms. Power has to be acquired and once acquired, it needs to be exercised, sustained, and preserved. Stromquist (1995) wrote that empowerment included both cognitive and psychological elements. It involved "women's understanding of their conditions of subordination and the causes of such conditions at both micro and macro levels of society. It involved understanding the self and the need to make choices that might go against cultural and social expectations". Gibb (2008) conducted a study of a microcredit program in the Bolivian Cities La Paz and El Alto. She carried out about 100 interviews, including women beneficiaries and a control group of women with no access to the credit program. The group of beneficiaries was split into a target group (poor women) and a group with higher incomes. She found that the loan program did have a positive effect on the businesses of the women and household assets, but not on the level of education of the children or women's empowerment. Concerning the latter, she looked at how the important decisions in the household were made, and at the division of labor regarding household chores. The most important decisions were made jointly by men and women in all groups, but in the control group, it occurred a bit more often than men took important decisions on their own. On the other hand, men in the control group proved more cooperative in carrying out household tasks than in the groups where women had had access to credit. In this area, women with access to microcredit were not empowered. From the above review of literature and research, it can be rightly stated that very few studies have been conducted in the area of women empowerment through a comparative study. But no study has been conducted through a comparative study of Grameen Bank and BRAC in Tangail District. Thus, the study covering the roles of microcredit on women empowerment and assess the roles of Grameen Bank and BRAC on women empowerment in Tangail District, which opens new areas for further research.

\section{ili. Conceptual Framework}

Microcredit: Microcredit is a way of delivering loans to poor individuals and is often suggested to be a way out of poverty. Microfinance institutions provide microcredit to individuals via their microcredit programs. In addition, microfinance institutions usually provide saving and insurance services (Graflund, 2013). Microcredit builds on the premise that financial services are needed to make investments in human capital, to smooth out consumption and to overcome unexpected shocks. It 
can be seen as a solution to include previously excluded poor groups, without access to credit, to the financial market so that they may rise out of poverty by them. Microcredit makes a positive economic cycle possible. Microcredit granted to a borrower is invested, which generates an income. The loan can be then repaid to the microfinance institution, and the borrower may then access another microcredit and eventually increase purchasing power and social recognition (Graflund, 2013). Dobra (2011) argues that microcredit not only opens up the opportunity of self-employment but also contributes to the improvement of the situation for the entire household. Furthermore, it positively affects the social condition of underprivileged individuals by promoting self-confidence and expanding the capacity to play a more vital role in society (Dobra, 2011).

Women Empowerment: The World Bank (2009) defines empowerment as "the process of increasing the capacity of individuals or groups to make choices and to transform those choices into desired actions and outcomes. Central to this process is actions which both build individual and collective assets and improve the efficiency and fairness of the organizational and institutional context which govern the use of these assets" (The World Bank, 2009). Amartya Sen (1993) explains that the freedom to lead different types of life is reflected in a person's capability set. A person's capability depends on a variety of factors, including social arrangements and personal characteristics. However, the full accounting of individual freedom goes beyond the capabilities of individual living. For example, if a person fear to choose to live in a certain way, even though she could live that way if she took to, can it be said that she does have the freedom to live that way (Sen, 1993, p. 31, 32). Empowerment is the process that relates to the power of an individual to redefine his or her possibilities and to have the ability to act upon them (Graflund, 2013). Kabeer (1998) further defines empowerment as "the expansion in people's ability to make strategic life choices in a context where this ability was previously denied to them." Accordingly, empowerment is about the improvement of an individual's capabilities to make a difference in their settings, which in turn affects their life. Empowerment also relates to the influence of an individual on social and cultural norms in society. In contrast to many other terms, women's empowerment narrates to a process, a movement from one state to another. Empowerment also includes agency, in which women themselves are actors in the empowerment process. Furthermore, agency implies that women must not only be able to make a decision but be aware of their rights to make it (Kabeer N., 1998)

Microcredit and Women Empowerment: How does microcredit lead to women's empowerment? It enables women empowerment by placing capital in their hands and allowing them to earn an independent income and contribute economically to their households and communities. In theory, women invest the microcredit in their income- earning activity, either in the form of a microenterprise or agricultural production, which increases their control. In other words, involvement in a successful income-generating activity should translate into greater control and economic empowerment. Women's economic empowerment is then expected a lead to increased well-being for themselves and also their families. Furthermore, this economic empowerment is seen as enabling women to renegotiate changes in gender roles, which may lead to social empowerment. Microcredit may also lead to increased women empowerment through increased power in decision. making (Graflund, 2013).

\section{Methodology}

Research Design: The research area of this study was Tangail region that's why here used Cluster /Stratified Sampling method for data collection. The processes for the collection of primary data for this study were only questionnaires. The data has been collected by the door to door by women interviewed through a structured questionnaire. The interviews were administered personally, like most of the respondents were illiterate and did't know how to read or write. Same types of questions were asked to all the respondents. All respondents have answered all queries included in the questionnaire.

Sources of Data: For this study, both primary and secondary data has been used. Primary data has been provided by the female members of Grameen Bank and BRAC. The study has included all the female members of Grameen Bank and BRAC in Tangail district who take loans from those organizations. Fifty samples from Grameen Bank and fifty samples from BRAC total of 100 samples have been collected for the research of this study. Secondary data was retrieved from different Books and Magazines, Internet and related Journals, and Project Papers.

Statistical Techniques: In this paper, percentage analysis, cross tabulation, and paired t-test have been used to analyze and interpret the data.

Analysis of the Study: Total of 100 women answered questionnaires. All respondents had received microcredit from Grameen Bank or BRAC. Fifty of the respondents had received credit from Grameen Bank, and other 50 had received credit from BRAC. 


\section{Result and Discussion}

Table 1: Demographic Information

\begin{tabular}{|c|c|c|c|}
\hline \multicolumn{2}{|c|}{} & Grameen Bank & BRAC \\
\cline { 2 - 4 } & & Percent & Percent \\
\hline \multirow{4}{*}{ Age } & $20-30$ & 30.0 & 38.0 \\
\cline { 2 - 4 } & $31-40$ & 18.0 & 32.0 \\
\cline { 2 - 4 } & $41-50$ & 38.0 & 30.0 \\
\cline { 2 - 4 } & $51-60$ & 14.0 & 00.0 \\
\hline \multirow{4}{*}{ Educational qualifications } & Illiterate & 60.0 & 44.0 \\
\cline { 2 - 4 } & Primary & 38.0 & 54.0 \\
\cline { 2 - 4 } & Secondary & 2.0 & 2.0 \\
\cline { 2 - 4 } & College & 0.00 & 00.0 \\
\cline { 2 - 4 } & Others & 0.00 & 0.00 \\
\hline \multirow{4}{*}{ Family members } & $2-4$ & 40.0 & 50.0 \\
\cline { 2 - 4 } & $5-7$ & 54.0 & 44.0 \\
\cline { 2 - 4 } & $8-10$ & 2.0 & 6.0 \\
\cline { 2 - 4 } & $11-$-Above & 4.0 & 00 \\
\hline \multirow{3}{*}{ Children } & $0-2$ & 42.0 & 52.0 \\
\cline { 2 - 4 } & $3-5$ & 54.0 & 44.0 \\
\hline \multirow{2}{*}{ Children going to school } & $6-$ Above & 4.0 & 26.0 \\
\hline
\end{tabular}

Source: Survey data

Table 1 shows that most of the women's age of Grameen Bank respondents are in the range of 41-50, and most of the women's ages of BRAC respondents are in the age of 20-30. Total $60 \%$ of the women of Grameen Bank respondents are illiterate, and 38\% women have completed primary education. On the other hand, about $54 \%$ of the women of BRAC Bank respondents have completed primary schooling and $44 \%$ of the women are illiterate. 54\% of the Grameen
Bank respondents' family members are in the range of $5-7$ and the $40 \%$ is in $2-4$ members. Almost $50 \%$ of the BRAC respondents' family members are in the range of $2-4$, and then $44 \%$ range is in $5-7$. About $54 \%$ of respondents of Grameen Bank have 0-2 children and $52 \%$ of respondents of BRAC have $0-2$ children. Most of the respondents' children of both Grameen Bank and BRAC are going to school.

Table 2: Decision-Making Indicators

\begin{tabular}{|c|c|c|c|}
\hline \multicolumn{2}{|c|}{ Decision-Making Indicators } & Grameen Bank & BRAC \\
\cline { 3 - 4 } & & Percent & Percent \\
\hline \multirow{2}{*}{ Expressing opinions freely in the family } & Yes & 98.0 & 100.0 \\
\cline { 2 - 4 } & No & 2.0 & 00.0 \\
\hline Make a small purchase (e.g. dress) without consulting \\
husband & Yes & 98.0 & 98.0 \\
\cline { 2 - 4 } & No & 2.0 & 2.0 \\
\hline Have a say in whether to work outside home & Yes & 46.0 & 32.0 \\
\cline { 2 - 4 } & No & 54.0 & 68.0 \\
\hline Have a say in whether to buy or sell property & Yes & 78.0 & 74.0 \\
\cline { 2 - 4 } & No & 22.0 & 26.0 \\
\hline Have a say in whether or not to send children to school & Yes & 70.0 & 90.0 \\
\cline { 2 - 4 } & No & 30.0 & 10.0 \\
\hline
\end{tabular}


Table 2 shows that 98\% of Grameen Bank respondents can express their opinion freely in the family, where $100 \%$ of BRAC respondents can express their opinion freely in the family. Maximum Grameen Bank and BRAC respondents can make a small purchase (e.g., dress) without consulting husband. About $46 \%$ of Grameen Bank respondents have a say in whether to work outside the home where $32 \%$ of BRAC respondents have a say in whether to work outside home. Majority of respondents of both Grameen Bank and BRAC have a say in whether to buy or sell the property. About $70 \%$ of Grameen Bank respondents have a say in whether or not to send children to school where $90 \%$ of BRAC respondents have a say in whether or not to send children to school.

Table 3: Ownership of Assets Indicators

\begin{tabular}{|l|c|c|c|}
\hline \multicolumn{2}{|c|}{ Ownership of Assets Indicators } & Grameen Bank & BRAC \\
\cline { 3 - 4 } & & Percent & Percent \\
\hline Land ownership in respondents own name & Yes & 26.0 & 26.0 \\
\cline { 2 - 4 } & No & 74.0 & 74.0 \\
\hline $\begin{array}{l}\text { The respondent's personal own property or valuables } \\
\text { (e.g. jewelry) }\end{array}$ & Yes & 78.0 & 78.0 \\
\cline { 2 - 4 } & No & 22.0 & 22.0 \\
\hline Respondent's independent savings & Yes & 76.0 & 70.0 \\
\cline { 2 - 4 } & No & 24.0 & 30.0 \\
\hline
\end{tabular}

Source: Survey data

Table 3 shows that 26\% of Grameen Bank and BRAC respondents have land ownership in their name, $78 \%$ of Grameen Bank and BRAC respondents have their property or valuables (e.g., jewelry). About $76 \%$ of

Grameen Bank respondents have independent savings where $70 \%$ of BRAC respondents have sovereign savings.

Table 4: Voice indicators

\begin{tabular}{|l|c|c|c|}
\hline \multicolumn{2}{|c|}{ Voice indicators } & Grameen Bank & BRAC \\
\cline { 3 - 4 } \multicolumn{2}{|c|}{} & Percent & Percent \\
\hline Comfortable giving opinion in the presence of husband & Yes & 98.0 & 94.0 \\
\cline { 2 - 4 } & No & 2.0 & 6.0 \\
\hline People in respondent family listen to ideas and opinions & Yes & 98.0 & 96.0 \\
\cline { 2 - 4 } & No & 2.0 & 4.0 \\
\hline People in the village listen to ideas and opinions & Yes & 70.0 & 62.0 \\
\cline { 2 - 4 } & No & 30.0 & 38.0 \\
\hline
\end{tabular}

Source: Survey data

Table 4 shows that $98 \%$ of Grameen Bank respondents can give an opinion in the presence of husband comfortably where $94 \%$ of BRAC respondents can express views in the presence of husband comfortably. About $98 \%$ of Grameen Bank respondents' family people listen to ideas and opinions of respondents where $96 \%$ of BRAC respondents' family people listen to notions and opinions of respondents. About $70 \%$ of Grameen Bank respondents' village people listen to thoughts and opinions of respondents where $62 \%$ of BRAC respondents' village people listen to sentiments of respondents.

Table 5: Mobility Indicators

\begin{tabular}{|c|c|c|c|}
\hline \multicolumn{2}{|c|}{ Mobility Indicators } & Grameen Bank & BRAC \\
\cline { 3 - 4 } & & Percent & Percent \\
\hline \multirow{2}{*}{ Respondents who can move independently } & Yes & 100.0 & 100.0 \\
\cline { 3 - 4 } & No & 00.0 & 00.0 \\
\hline Comfortable going to the local market without asking permission & Yes & 80.0 & 72.0 \\
\cline { 2 - 4 } & No & 20.0 & 28.0 \\
\hline \multirow{2}{*}{$\begin{array}{c}\text { Comfortable going to the neighboring village without asking for } \\
\text { permission from the husband or other family members }\end{array}$} & Yes & 100.0 & 100.0 \\
\cline { 2 - 4 } & No & 00.0 & 00.0 \\
\hline
\end{tabular}

Source: Survey data 
Table 5 shows that $100 \%$ of both Grameen Bank and BRAC respondents can move independently. Majority of Grameen Bank and BRAC respondents can go to the local market without asking permission from the husband or other family members. All respondents of both Grameen Bank and BRAC can go to the neighboring village without asking for permission from the husband or other family members.

Table 6: Percentages of the Purpose of Getting Microfinance by Respondents

\begin{tabular}{|c|c|c|c|c|c|}
\hline \multirow{2}{*}{$\begin{array}{c}\text { Serial } \\
\text { No. }\end{array}$} & \multirow{2}{*}{ Options } & \multicolumn{2}{|c|}{ Grameen Bank } & \multicolumn{2}{c|}{ BRAC } \\
\cline { 3 - 6 } & Frequency & Percent & Frequency & Percent \\
\hline 1 & Household purpose & 29 & 58.0 & 25 & 50.0 \\
\hline 2 & To start business & 12 & 24.0 & 14 & 28.0 \\
\hline 3 & To promote existing business & 7 & 14.0 & 10 & 20.0 \\
\hline 4 & Educational purpose & 2 & 4.0 & 1 & 2.0 \\
\hline 5 & Low rate of interest & 00 & 00.0 & 00 & 00.0 \\
\hline & Total & 50 & 100.0 & 50 & 100.0 \\
\hline
\end{tabular}

Source: Survey data

Table 6 shows that 58\% of Grameen Bank and 50\% of BRAC respondents take microfinance for household purpose.

Table 7: Reduce Poverty Level

\begin{tabular}{|c|c|c|c|c|c|}
\hline \multirow{2}{*}{$\begin{array}{c}\text { Serial } \\
\text { No. }\end{array}$} & & \multicolumn{2}{|c|}{ Grameen Bank } & \multicolumn{2}{c|}{ BRAC } \\
\cline { 3 - 6 } & & Frequency & Percent & Frequency & Percent \\
\hline 1 & To a greater extent & 9 & 18 & 16 & 32 \\
\hline 2 & To some extent & 22 & 44 & 25 & 50 \\
\hline 3 & To low extent & 19 & 38 & 9 & 18 \\
\hline \multicolumn{2}{r|r}{} & 50 & 100.0 & 50 & 100.0 \\
\hline
\end{tabular}

Source: Survey Data

Table 7 shows that $44 \%$ of respondents of Grameen Bank stated that microfinance had reduced their poverty level to some extent, $38 \%$ respondents identified to the low extent and only $18 \%$ respondent specified to a greater extent. About $50 \%$ of respondents

of BRAC listed that microfinance has reduced their poverty level to some extent, $32 \%$ respondents stated to a greater extent, and only $18 \%$ respondent stated to a low range.

Table 8: Increase Family Income

\begin{tabular}{|c|c|c|c|c|c|}
\hline \multirow{2}{*}{$\begin{array}{c}\text { Serial } \\
\text { No. }\end{array}$} & & \multicolumn{2}{|c|}{ Grameen Bank } & \multicolumn{2}{|c|}{ BRAC } \\
\hline & & Frequency & Percent & Frequency & Percent \\
\hline 1 & To a greater extent & 12 & 24 & 11 & 22 \\
\hline 2 & To some extent & 32 & 64 & 37 & 74 \\
\hline 3 & Not at all & 06 & 12 & 02 & 04 \\
\hline & Total & 50 & 100.0 & 50 & 100.0 \\
\hline
\end{tabular}

Source: Survey Data

Table 8 shows that $64 \%$ of Grameen Bank respondents stated that their family income has increased to some extent, $24 \%$ said their family income has improved to a greater extent and 6\% said their family income has not augmented after joining Grameen Bank. About $74 \%$ of Grameen Bank respondents stated that their family income has greater than before to some extent, $22 \%$ said their family income has increased to a greater extent, and $4 \%$ said their family income has not better after joining BRAC. 
Table 9: Age * Educational Qualification Cross-tabulation (Grameen Bank)

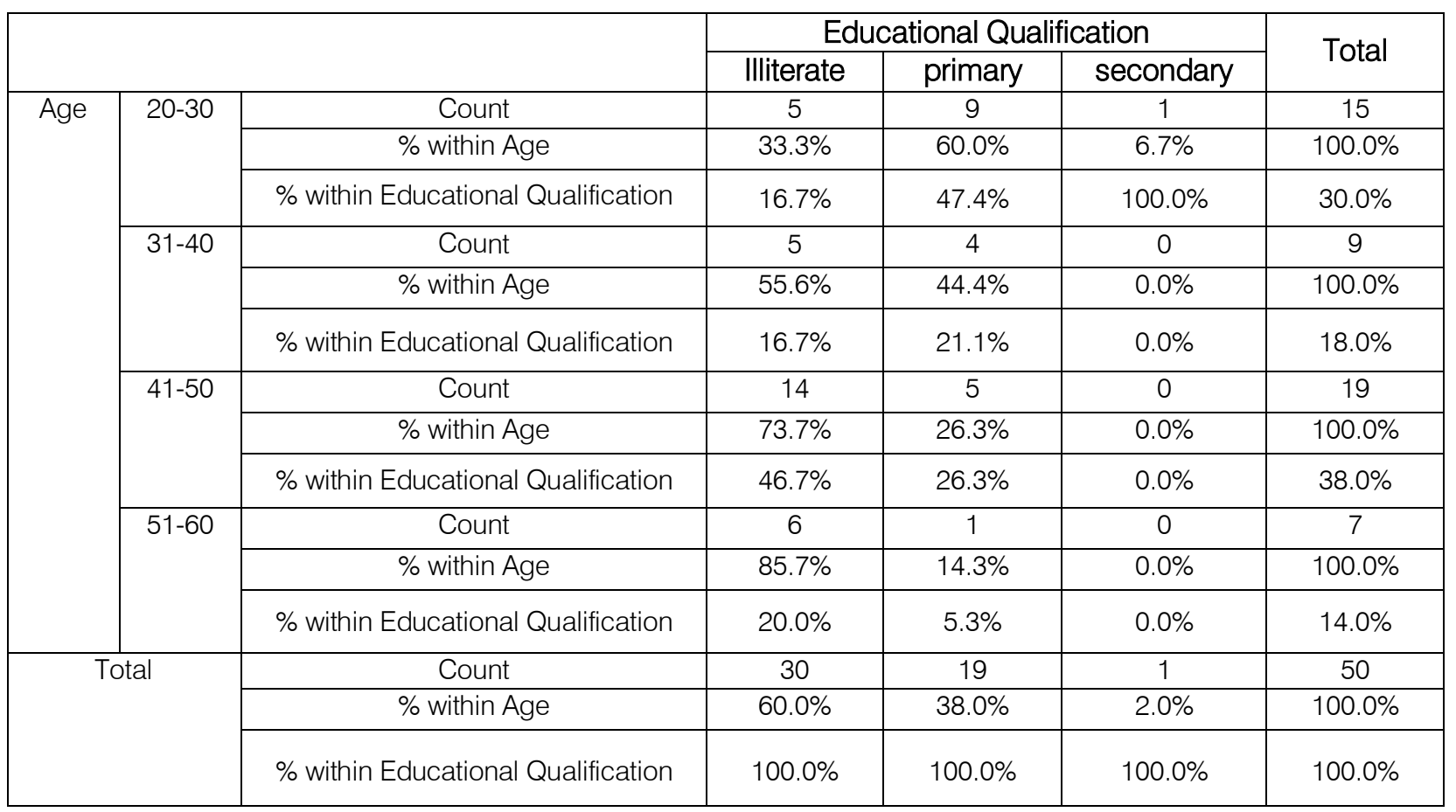

Source: Survey data

Table 9 shows that from the Grameen Bank respondents $85.7 \%$ illiterate women are in the range of $51-60$ ages, $60 \%$ of women who passed primary schooling are in the array of $20-30$ ages and $6.7 \%$ women who passed secondary education are in the age of 20-30.

Table 10: Age * Educational Qualification Cross-tabulation (BRAC)

\begin{tabular}{|c|c|c|c|c|c|c|}
\hline & \multicolumn{3}{|c|}{ Educational Qualification } & \multirow{2}{*}{ Total } \\
\hline & & & Illiterate & Primary & Secondary & \\
\hline \multirow[t]{9}{*}{ Age } & \multirow[t]{3}{*}{$20-30$} & Count & 1 & 17 & 1 & 19 \\
\hline & & $\%$ within Age & $5.3 \%$ & $89.5 \%$ & $5.3 \%$ & $100.0 \%$ \\
\hline & & \% within Educational Qualification & $4.5 \%$ & $63.0 \%$ & $100.0 \%$ & $38.0 \%$ \\
\hline & \multirow[t]{3}{*}{$31-40$} & Count & 9 & 7 & 0 & 16 \\
\hline & & $\%$ within Age & $56.2 \%$ & $43.8 \%$ & $0.0 \%$ & $100.0 \%$ \\
\hline & & \% within Educational Qualification & $40.9 \%$ & $25.9 \%$ & $0.0 \%$ & $32.0 \%$ \\
\hline & \multirow[t]{3}{*}{$41-50$} & $\mathrm{C}_{\text {ount }}$ & 12 & 3 & 0 & 15 \\
\hline & & $\%$ within Age & $80.0 \%$ & $20.0 \%$ & $0.0 \%$ & $100.0 \%$ \\
\hline & & \% within Educational Qualification & $54.5 \%$ & $11.1 \%$ & $0.0 \%$ & $30.0 \%$ \\
\hline \multirow{3}{*}{\multicolumn{2}{|c|}{ Total }} & Count & 22 & 27 & 1 & 50 \\
\hline & & \% within Age & $44.0 \%$ & $54.0 \%$ & $2.0 \%$ & $100.0 \%$ \\
\hline & & \% within Educational Qualification & $100.0 \%$ & $100.0 \%$ & $100.0 \%$ & $100.0 \%$ \\
\hline
\end{tabular}

Source: Survey data

Table 10 shows that from the BRAC respondents $80 \%$ illiterate women are in the range of 41 50 ages, $89 \%$ of women who passed primary schooling are in the array of $20-30$ ages and $5.3 \%$ women who passed secondary education are in the age of 20-30. 
Table 11: Age * Number of Children Cross-tabulation (Grameen Bank)

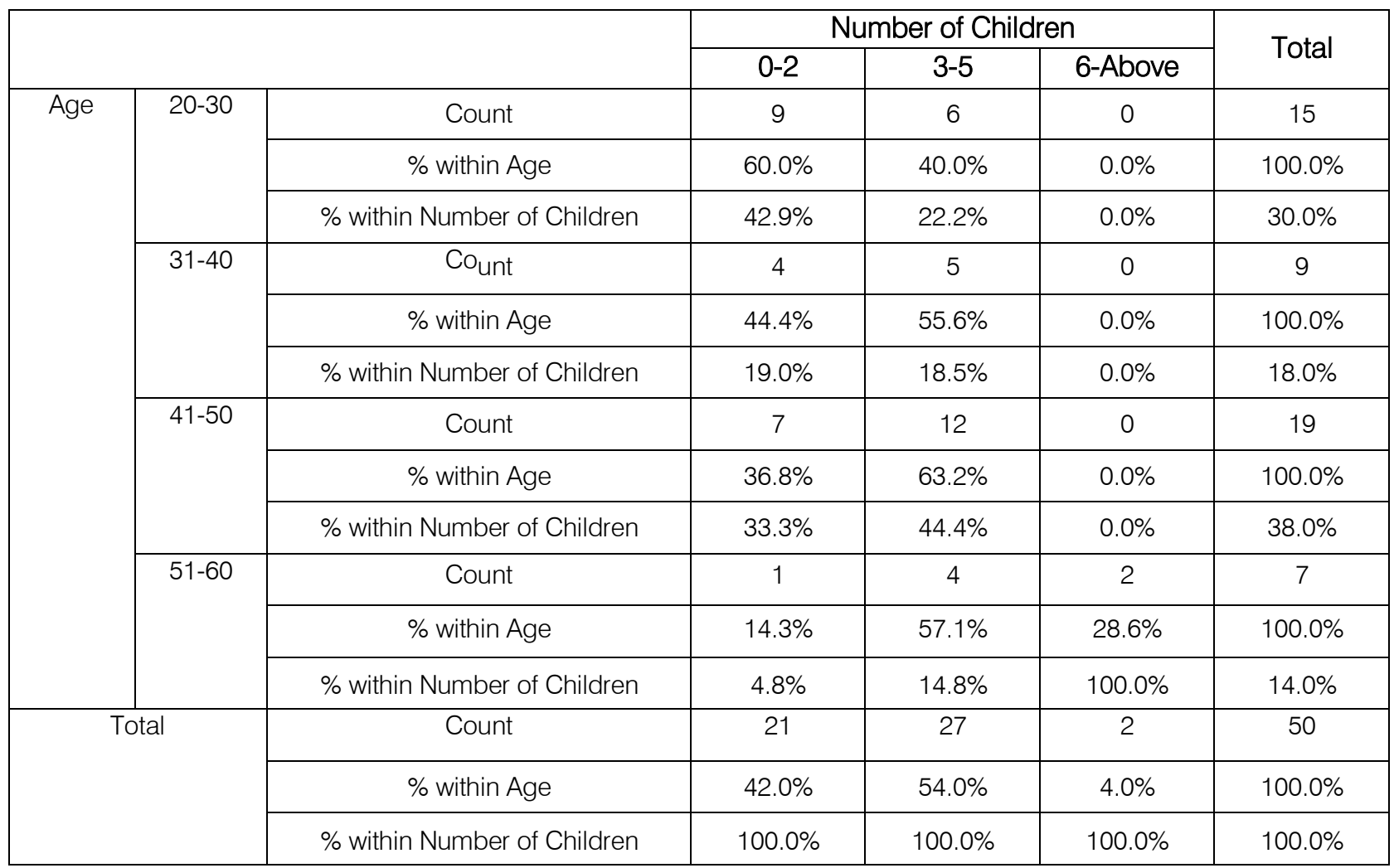

Source: Survey data

Table 11 shows in 20-30 age range $42.9 \%$ women of Grameen Bank have 0 to 2 children, and $22.2 \%$ women have 3 to 5 children. In 31-40 age ranges, $19.0 \%$ women have 0 to 2 children, and $18.5 \%$ women have 3 to 5 children. In $41-50$ ages' women, 33.3\% have
0 to 2 children, and $44.4 \%$ have 3 to 5 children. In 51-60 ages' women, $4.8 \%$ have 0 to 3 children, $14.8 \%$ women have 3 to 5 children, and $100.0 \%$ have six above children.

Table 12: Age * Number of Children Cross-tabulation (BRAC)

\begin{tabular}{|c|c|c|c|c|c|c|}
\hline & \multicolumn{3}{|c|}{ Number of Children } & \multirow{2}{*}{ Total } \\
\hline & & & $0-2$ & $3-5$ & 6-Above & \\
\hline \multirow[t]{9}{*}{ Age } & \multirow[t]{3}{*}{$20-30$} & Count & 13 & 6 & 0 & 19 \\
\hline & & $\%$ within Age & $68.4 \%$ & $31.6 \%$ & $0.0 \%$ & $100.0 \%$ \\
\hline & & \% within Number of Children & $50.0 \%$ & $27.3 \%$ & $0.0 \%$ & $38.0 \%$ \\
\hline & \multirow[t]{3}{*}{$31-40$} & Count & 8 & 8 & 0 & 16 \\
\hline & & $\%$ within Age & $50.0 \%$ & $50.0 \%$ & $0.0 \%$ & $100.0 \%$ \\
\hline & & \% within Number of Children & $30.8 \%$ & $36.4 \%$ & $0.0 \%$ & $32.0 \%$ \\
\hline & \multirow[t]{3}{*}{$41-50$} & Count & 5 & 8 & 2 & 15 \\
\hline & & $\%$ within Age & $33.3 \%$ & $53.3 \%$ & $13.3 \%$ & $100.0 \%$ \\
\hline & & \% within Number of Children & $19.2 \%$ & $36.4 \%$ & $100.0 \%$ & $30.0 \%$ \\
\hline \multirow{3}{*}{\multicolumn{2}{|c|}{ Total }} & Count & 26 & 22 & 2 & 50 \\
\hline & & $\%$ within Age & $52.0 \%$ & $44.0 \%$ & $4.0 \%$ & $100.0 \%$ \\
\hline & & \% within Number of Children & $100.0 \%$ & $100.0 \%$ & $100.0 \%$ & $100.0 \%$ \\
\hline
\end{tabular}

Source: Survey data

Table 12 shows in $20-30$ age range $50 \%$ women respondents of BRAC have 0 to 2 children, and $27.3 \%$ women have 3 to 5 children. In 31-40 age ranges, 30.0\% women have 0 to 2 children, and $36.4 \%$ women have 3 to 5 children. In $41-50$ age ranges, $19.2 \%$ have 0 to 2 children, $36.4 \%$ have 3 to 5 children, and $100.0 \%$ have 6 and above children. 
Table 13: Paired Samples Test (Grameen Bank)

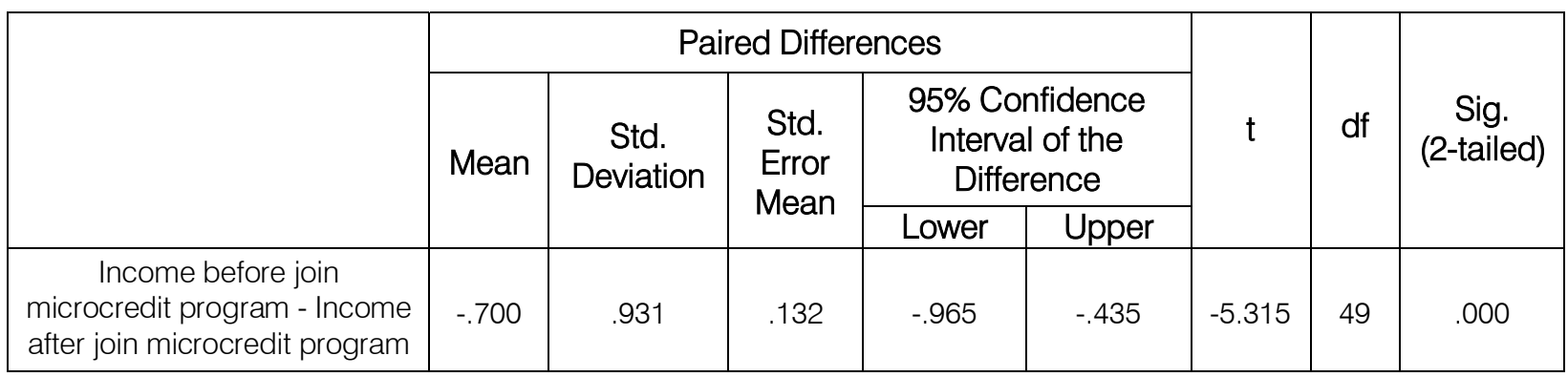

Table 14: Paired Samples Test (BRAC)

\begin{tabular}{|c|c|c|c|c|c|c|c|c|}
\hline & \multicolumn{5}{|c|}{ Paired Differences } & \multirow{3}{*}{$\mathrm{t}$} & \multirow{3}{*}{ df } & \multirow{3}{*}{$\begin{array}{c}\text { Sig. } \\
\text { (2-tailed) }\end{array}$} \\
\hline & \multirow[t]{2}{*}{ Mean } & \multirow{2}{*}{$\begin{array}{c}\text { Std. } \\
\text { Deviation }\end{array}$} & \multirow{2}{*}{$\begin{array}{l}\text { Std. Error } \\
\text { Mean }\end{array}$} & \multicolumn{2}{|c|}{$\begin{array}{l}\text { 95\% Confidence } \\
\text { Interval of the } \\
\text { Difference }\end{array}$} & & & \\
\hline & & & & Lower & Upper & & & \\
\hline $\begin{array}{l}\text { Income before join } \\
\text { microcredit program -Income } \\
\text { after join microcredit program }\end{array}$ & -.920 & .752 & .106 & -1.134 & -.706 & -8.655 & 49 & .000 \\
\hline
\end{tabular}

Since the significant value is .000 for both Grameen Bank and BRAC, the hypothesis is accepted. That means there is a positive relationship between income before joining the microcredit program and after joining the microcredit program. Thus the microcredit significantly increases the family income.

\section{Vi. Conclusion and Recommendations}

Microfinance programs by different NGOs, especially by BRAC and Grameen Bank, are playing an central role in reducing poverty and thus, empowering rural women in Bangladesh. Likewise, other MFls are also doing well in this regard as like ASA, TMSS, SHAKTI, BURO, and so on. In particular, more than 1000 MFIs are in operation Bangladesh, serving over 85,000 villages, and more than 37 percent of the households have access to microcredit programs (Rahman et al., 2017). However, large $10 \mathrm{MFI}$ and Grameen Bank represent 87 percent of total savings of the sector and 81 percent of over-all outstanding loan (Bangladesh Bank, 2019). Our study found that microfinance programs have a positive impact on empowering rural women in Bangladesh. Women empowerment about family decision making, ownership of assets, expressing an opinion in the society, free mobility has increased significantly after taking microcredit facilities from MFIs. However, MFIs must monitor the use of loan by female borrowers and make sure that that loan is not misused by their husbands. Moreover, MFIs should assist women by finding different profitable small and medium trade and business areas through market research and surveys and provide technical assistance and training in those particular areas, which will increase loan repayment rate of the women and make them well off. The government should also take different programs like launching technical and vocational training centers for women, facilitating adult education programs, and monitoring interest rate of MFIs.

\section{Limitations and Future Research DiRECTIONS}

There are several limitations to this study. First, the study is conducted in Tangail region collecting data from the members of two big MFIs, e.g., BRAC and Grameen Bank. Future Research may be directed by taking some others MFIs in consideration from different rural areas in Bangladesh. Second, this study takes responses from a small number of respondents which may not reveal the real scenario of rural women empowerment through microcredit. As such, future research should collect data from more respondents. Third, in many cases, it was found that women felt hesitate while responding with the surveyors as their husbands are staying beside them. As a result, they couldn't express real facts regarding different personal and family-related issues.

\section{References Références Referencias}

1. Aruna, M., \& Jyothirmayi, R. (2011). The role of microfinance in women empowerment: A study on the SHG Bank Linkage Program in Hyderabad (Andhra Pradesh). Indian Journal of Commerce and Management Studies, 2, 77-95.

2. Bangladesh Bank, Retrieved from https://www.bb. org.bd/fnansys/mfi.php 
3. DFID. (2000). Report on Poverty Elimination and the Empowerment of Women. Stairway Communications. UK. Retrieved from http://www.dfid.gov.uk/Pubs/ files/tspgender.pdf

4. Dobra, A. (2011). Microfinance: Champion in Poverty Alleviation and Failure in Female Empowerment. International Politik and Gesellschaft, 3, 134-144.

5. Elissa, M. (2006). Women and microfinance: Why we should do more? Women, leadership and equality Papers. Retrieved from http://digitalcommons.law. umaryland.edu/wle papers/21.

6. Gibb, S. (2008). Microfinance's impact on education, poverty, and empowerment: A case study from the Bolivian altiplano. Uppsala: Institute for Advanced Development Studies, Uppsala University, 04.

7. Goetz, A. M., \& Sen Gupta, R. (1996). Who takes the Credit? Gender, Power, and Control Over Loan Use in Rural Credit Programme in Bangladesh. World Development, 24(1), 45-63.

8. Graflund, F. (2013). The impact of microcredit on women's empowerment-a case study of microcredit in the Tangail district, Bangladesh. National ekonomiska institution vid lunds universitet.

9. Hashemi, S. M., Schuler, S. R., \& Riley, A. P. (1996). Rural Credit Programs and Women's Empowerment in Bangladesh. World Development, 24(4), 635-653.

10. Hussain, A., \& Nargis, N. (2008). A Welfare Economic Analysis of the Impact of Microfinance in Bangladesh. Nilkhet, Dhaka-1000, Bangladesh.

11. Kabeer, N. (1998). 'Money Can't Buy Me Love?' Reevaluating Gender, Credit and Empowerment in Rural Bangladesh. Institute of Development Studies.

12. Kabeer, N. (2001). Conflicts over credit: Reevaluating the empowerment potential of loans to women in rural Bangladesh. World Development, 29(1), 63-84.

13. Khandker, R. S. (1998). Fighting Poverty with Microcredit - Experience in Bangladesh. Great Clarendon Street, Oxford Ox26DP, United Kingdom: Oxford University Press.

14. Khandker, S., \& Pitt, M. (1998). The Impact of Group-Based Credit Programs on Poor Households in Bangladesh: Does the Gender of Participants Matter? Political Economy, 106(5), 958-996.

15. King, E. M. (2008). Vietnam's Decree on Microfinance: A Flawed Attempt to Create an Enabling Legal Environment for Microfinance. Pacific Rim Law \& Policy Journal, 17, 187-207.

16. Le, Q. V., \& Reven, V. S. (2015). Woman entrepreneurship in rural Vietnam: success and motivational factors. The Journal of Developing Areas, 49, 57-76.

17. Longwe, S. H., \& Clarke, R. (1994). Women in Development, Culture and Youth: Workshop
Reading. Longwe Clarke and Associates. Lusaka, Zambia

18. Malathi, S., \& Vijayarani, K. (2012). Microfinance and Women Empowerment in the Rural Areas of Cuddalore District of Tamilnadu. Language in India, 12, 174-182.

19. Mizan, A. N. (1993). Women's Decision Making Power in Rural Bangladesh: A case study of Grameen. In A. Wahid (Ed.), The Grameen Bank: The Poverty Relief in Bangladesh (pp. 97-126). Dhaka, Bangladesh: West View Press.

20. MOWCA. (2008). Ministry of women and children affairs: government of the people's republic of Bangladesh. Retrieved from http://www.mowca. gov.bd/

21. Moyle, T. L., Dollard, M., \& Biswas, S. N. (2006). Personal and Economic Empowerment in Rural Indian Women: A Self Help Group Approach. International Journal of Rural Management, 2, 245-266

22. Naved, R. T. (1994). Empowerment of Women: Listening to the Voices of Women. The Bangladesh Development Studies, Women Development and Chance, 22, 121-178.

23. NWDP. (2008). National Women Development Policy. women status in Bangladesh, in national woman development policy, ministry of women and children affairs: Government of the People's Republic of Bangladesh. Retrieved from http://mowca.gov. bd/pages/Women-2008.html

24. Pillai, J. K. (1995). Women and Empowerment. Gyan Publishing House, 23-24.

25. Pitt, M., Khandker, S., \& Cartwright, J. (2003). Does Micro-Credit Empower Women? Evidence from Bangladesh. World Bank: Policy Research Working Paper. Washington D.C >

26. Sanyal, P. (2009). From Credit to Collective Action: The Role of Microfinance in Promoting Women's Social Capital and Normative Influence. American Socialogical Review, 74, 529-550.

27. Sarumathi, S., \& Mohan, K. (2011). Role of Micro Finance in Women's Empowerment (An Empirical study in Pondicherry region rural SHG's). Journal of Management and Science, 1, 1-8.

28. Sebstad, J., \& Cohen, M. (2003). Financial education for the poor microfinance opportunities. Retrieved from http://www.microfinanceopportuni ties.org/docs/Financial Education for the Poor\%20 April\%202003.pdf

29. Shahnaj Parveen and Ingrid-Ute Leonhäuser 2004 "Empowerment of Rural Women in Bangladesh: A Household Level Analysis" Deutscher TropentagBerlin, 5-7 October 2004, Conference on Rural Poverty Reduction through Research for Development and Transformation. 
30. Stromquist, N. P. (1995). The Theoretical and Practical Base for Empowerment. Women, Education and Empowerment: Pathways Towards Autonomy. Hamburg, Germany: United Nations Educational, Scientific and Cultural Organization (UNESCO).

31. Sultana, S., \& Hasan, S. S. (2010). Impact of Microcredit on Economic Empowerment of Rural Women. The Agriculturists, 8, 43-49.

32. The Daily Star (2018), Retrieved from https://www.thedailystar.net/supplements/womensparticipation-the-job-market-1545181

33. The World Bank. (2009). What is empowerment. Retrieved from http://go.worldbank.org/V45HD 4P100.

34. Von, B. D., Damball, E., \& R, M. (1995). Supporting women group in Tanzania through credit: Is this a strategy for empowerment? Copenhagen: Center for Development Research. 